\title{
ORIGINAL
}

\section{Relationship between Physical Properties of a Food Bolus and Initiation of Swallowing}

\author{
Kouichi Shiozawa, Kaoru Kohyama* and Keiji Yanagisawa \\ Department of Physiology, Tsurumi University School of Dental Medicine \\ *National Food Research Institute \\ 2-1-3 Tsurumi, Tsurumi-ku, Yokohama 230-8501, Japan \\ *2-1-12 Kannondai, Tsukuba 305-8642, Japan
}

(Received on December 10, 2002 ; Accepted on February 17, 2003)

Key words : texture/food bolus/swallowing/mastication/human

\begin{abstract}
To clarify the relationship between the physical properties of a food bolus and the initiation of swallowing, we measured the texture of food boluses collected from the oral cavity at three different stages of mastication: M stage, the halfway stage of mastication; L stage, immediately prior to swallowing : and $+20 \%$ stage, the number of chewing strokes $20 \%$ beyond a point at which swallowing would usually occur. Eleven healthy adult participants masticated highly adhesive rice cakes (RC), hard and brittle peanuts (P) and hard biscuits (HB). The texture of the bolus was measured by texture profile analysis. Hardness of the bolus decreased significantly from the M to L stage during mastication of all three types of food. This finding suggests that the decrease in hardness of a bolus may be a necessary factor for the initiation of swallowing, although it is not a sufficient factor by itself for the initiation of swallowing. For both the $\mathrm{P}$ and HB boluses, adhesiveness had a maximum value at the $\mathrm{L}$ stage immediately prior to swallowing, and cohesiveness increased significantly from the $\mathrm{M}$ to $\mathrm{L}$ stage. In contrast, adhesiveness of the RC bolus decreased significantly $(p<0.001)$ from the $M$ to $L$ stage, with cohesiveness remaining unchanged. These findings suggest that the initiation of swallowing during mastication of hard and brittle food commences once a clump bolus formed, while swallowing of highly adhesive food is triggered when adhesiveness of the bolus is sufficiently reduced to meet the swallowing threshold.
\end{abstract}

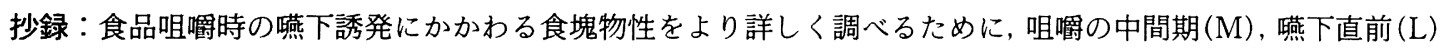
および嚥下までの咀嚼回数の $20 \%$ 余計に咀夁したとき $(+20 \%)$ の食塊をそれぞれ口腔内から回収し，その物性 をテクスチャー測定した。11名の成人被験者にモチ $(\mathrm{RC})$, ピーナッッ (P) およびハードビスケット (HB) を 咀嚼させた。食塊の硬さはいずれの食品咀噮でも嚥下直前には有意に減少したことから, 食塊の硬さの減少は嚥 下誘発の直接要因ではないものの, 重要な役割を果たしていることが示唆された。P および HB 食塊では曣下直 前には付着性は最大值を示し, また凝集性も增大した。これに対し RC 食塊では, 凝集性は変化しなかったが付着 性は有意（ $\mathrm{p}<0.001 ） に$ 減少した。これらの結果から, 硬く破砕しやすい食品咀嚼では 1 つにまとまった食塊が 形成された時点で, 一方, 付着性に富む食品咀嚼では食塊の付着性の程度が嚥下閾値まで減少した時点で, 嬩下 が誘発されることが示唆された。
}

\section{Introduction}

The initiation of swallowing during mastication is thought to be related to the physical properties of a food bolus ${ }^{1)}$. In the mid 90's, Printz and Lucas (1997) proposed a new model for the initiation of swallowing in which the optimum moment for swallowing was 
defined in terms of a peak cohesive force between the food particles of the bolus ${ }^{2}$. This model was based on the mastication of hard and brittle foods such as brazil nuts, and its applicability to diet foods remains to be classified. Moreover, actual changes in the physical properties of various types of food boluses during mastication are still not clear. In an attempt to elucidate which of the physical properties of a food bolus trigger swallowing, in the present study we measured the texture of food boluses collected from the oral cavity at three different stages during mastication of hard and brittle food, and also during mastication of highly adhesive food, in humans.

\section{Materials and Methods}

\section{Subjects}

Eleven healthy adult volunteers ( 3 male and 8 female ; mean age, $28.6 \mathrm{yrs}$ ) with functionally normal occlusion participated in this study after giving informed consent.

\section{Food samples}

Three types of food with different textures were prepared in $5 \mathrm{~g}$ units for use: highly adhesive rice cakes $(\mathrm{RC})$, hard and brittle peanuts $(\mathrm{P})$ and hard biscuits (HB). Peanuts (Denroku Co., Japan) and hard biscuits (kanpan, Sanritsuseika Co., Japan) were commercial products. Rice cakes were made by steaming a mixture of $100 \mathrm{~g}$ of rice flour (Miki-kokufun Co. Japan) and $90 \mathrm{~m} l$ of water for $20 \mathrm{~min}$.

\section{Experimental procedure}

To determined the average number of chewing strokes per food sample, participants masticated each of the food samples until swallowing as usual. Mastication was repeated more than three times for each test food sample. Food samples were supplied for participants in a random order. During mastication, electromyographic activity (EMG) of the masseter muscle was recorded using bipolar surface electrodes as previously described ${ }^{3,4}$. The number of chewing strokes until swallowing was counted from the bursting EMG activities and averaged for each of the food samples. The mean value of chewing strokes until

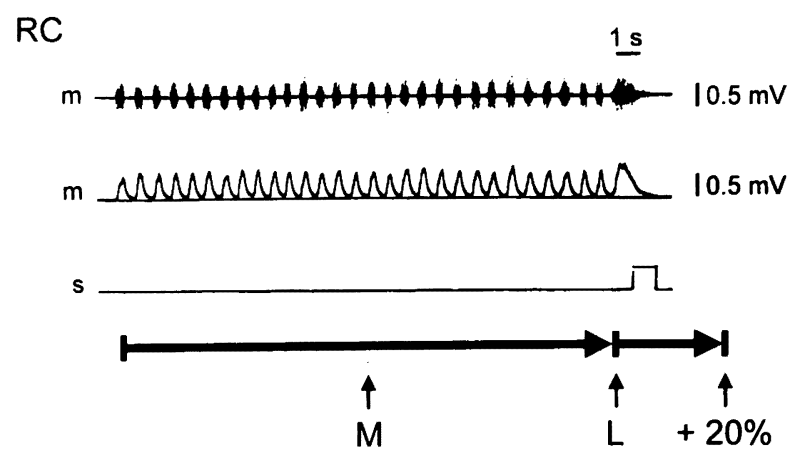

Fig. 1 Example of the masseter muscle EMG (m) recording during mastication of rice cake $(\mathrm{RC})$ from ingestion to swallowing. Food boluses were collected from the oral cavity at 3 time points during mastication: $\mathrm{M}$ indicates the $\mathrm{M}$ stage of mastication (number of chewing strokes at halfway stage of swallowing); L, L stage of mastication (immediately before swallowing); and $+20 \%$ stage of mastication (number of chewing strokes $20 \%$ beyond a point at which swallowing would normally occur). The third recording shows the swallowing signal (s). Participant pressed a button at the moment of commencement of swallowing during mastication.

swallowing obtained from eleven participants was $28.3 \pm 8.3$ in RC, $34.8 \pm 8.4$ in $\mathrm{P}$ and $39.4 \pm 9.3$ in HB. Next, as shown in Fig. 1, we calculated the number of chewing strokes at the halfway stage of mastication (M stage) for each food sample and the number of chewing strokes $20 \%$ beyond a point at which swallowing would usually occur ( $+20 \%$ stage).

The stage of mastication immediately before swallowing was termed "L stage". To collect the food bolus from the oral cavity at the three different stages of mastication (M stage ; L stage ; $+20 \%$ stage), participants masticated each food sample for the prescribed number of chewing strokes before spitting the food bolus into a cup. Participants masticated each test food sample at least three times.

\section{Measurement of bolus texture}

The food bolus collected from the oral cavity was placed in a glass ring (inner diameter, $20 \mathrm{~mm}$; height, $10 \mathrm{~mm}$ ) on a glass disc and then placed in a small box fixed to the moving stage of a creep meter (RE-3305, YAMADEN, Japan). Temperature and humidity 


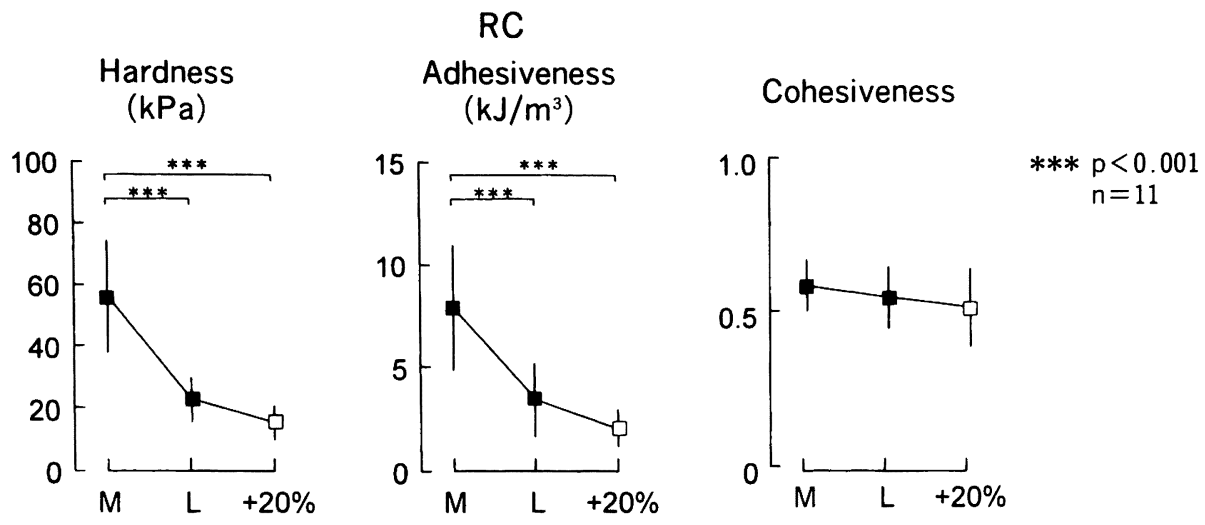

Fig. 2 Mean values of three texture parameters of hardness, adhesiveness and cohesiveness of rice cake boluses ( $\mathrm{RC}$ ) collected from the oral cavity at three different stages (M, L and $+20 \%$ stages) of mastication.

inside the box were maintained at $36.6-36.8^{\circ} \mathrm{C}$ and about $70 \%$, respectively. The texture of the bolus was measured according to a texture profile analysis ${ }^{5,6}$. Each sample was compressed twice using a plunger (diameter, $5 \mathrm{~mm}$ ) to $67 \%$ strain at a constant speed of $1 \mathrm{~mm} / \mathrm{s}$. Three texture parameters were obtained from the stress strain curve: hardness (peak stress during the first bite), adhesiveness (area surrounded by stress strain curve and the base line for the first bite), and cohesiveness (ratio of the work for the second bite to that for the first bite).

\section{Statistical analysis}

Data are expressed as means and standard deviations (SD). Analysis of variance (ANOVA) was used to determine statistically significant differences in texture parameters between the three boluses collected from the oral cavity at M, L and $+20 \%$ stages. Thereafter, all pairwise differences between means were tested using Bonferoni's multiple comparison. Differences were considered significant at $\mathrm{p}<0.05$.

\section{Results}

Figure 2 shows the change in mean value of the each of the three texture parameters of the $\mathrm{RC}$ boluses obtained from the eleven participants during the three stages of mastication. Hardness and adhesiveness of the $\mathrm{RC}$ bolus decreased significantly $(\mathrm{p}<0.001)$ from the $\mathrm{M}$ stage to the $\mathrm{L}$ stage, while no significant difference in cohesiveness of the RC bolus was noted. Hardness at the $M$ stage decreased by 41 percent at the $\mathrm{L}$ stage. Adhesiveness at the $\mathrm{M}$ stage decreased by 44 percent at the $\mathrm{L}$ stage.

Figure 3 shows the change in mean value of the three texture parameters of the $\mathrm{P}$ bolus during mastication. Hardness significantly $(p<0.001)$ decreased by 32 percent from the $\mathrm{M}$ stage to the $\mathrm{L}$ stage. In contrast, the cohesiveness of $\mathrm{P}$ bolus increased significantly $(p<0.05)$ from the $M$ to the $L$ stage. Cohesiveness was approximately doubled at the $\mathrm{L}$ stage. Adhesiveness had a maximum value $(1.90 \pm$ $0.89 \mathrm{~kJ} / \mathrm{m}^{3}$ ) at the L stage.

The change in mean value of each of the three texture parameters of the HB bolus during mastication is showed in Fig. 4. Hardness significantly $(\mathrm{p}<$ 0.001 ) decreased by 48 percent from the $\mathrm{M}$ to the $\mathrm{L}$ stage and also significantly $(\mathrm{p}<0.05)$ decreased by 50 percent from the $\mathrm{L}$ to the $+20 \%$ stage.

In contrast, cohesiveness significantly $(p<0.01)$ increased by 53 percent from the $\mathrm{M}$ to the $\mathrm{L}$ stage. Adhesiveness had a maximum value $(3.36 \pm 1.95 \mathrm{~kJ} /$ $\mathrm{m}^{3}$ ) at the L stage.

\section{Discussion}

In this study, we directly measured the texture of food boluses and investigated changes in their physi- 

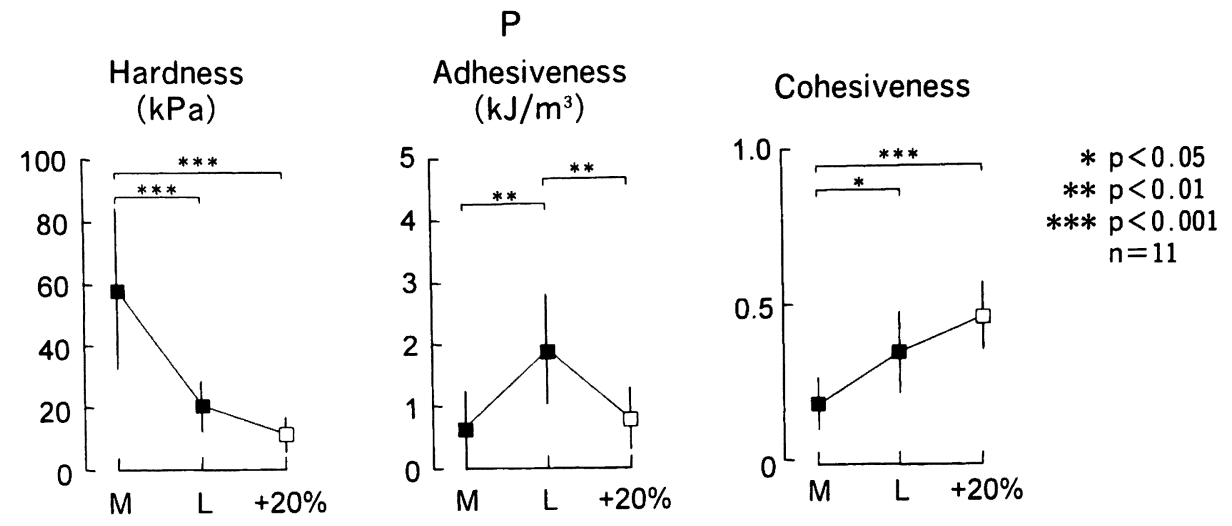

Fig. 3 Mean values of three texture parameters of hardness, adhesiveness and cohesiveness of peanut boluses (P) collected from the oral cavity at three different stages (M, L and $+20 \%$ stages) of mastication.
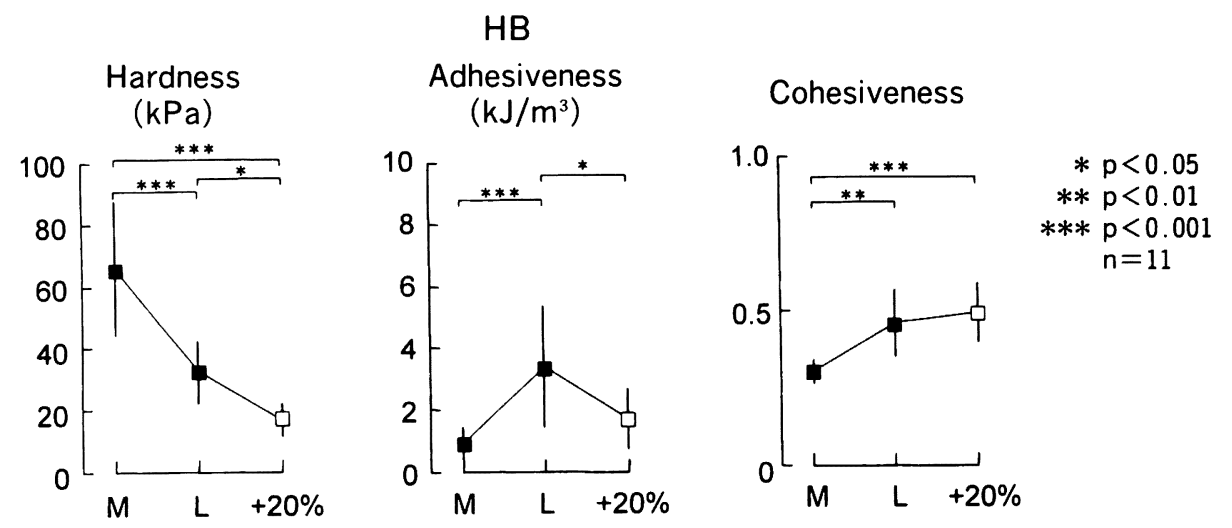

Fig. 4 Mean values of three texture parameters of hardness, adhesiveness and cohesiveness of hard biscuit boluses (HB) collected from the oral cavity at three different stages (M, L and $+20 \%$ stages) of mastication.

cal properties during mastication in order to elucidate which of the physical properties are related to the initiation of swallowing. The hardness of a food bolus was found to decrease significantly from the M stage to the L stage during mastication of all three types of test food in this study. This finding indicates that while this decrease in hardness is a necessary factor in the initiation of swallowing, it is not sufficient on its own to trigger swallowing, because the hardness of a bolus immediately prior to swallowing is known to vary with masticated food type ${ }^{4}$. Food particles are gradually reduced in size during solid food mastica$\operatorname{tion}^{7,8)}$, and it is this reduction that may be the main cause of the decrease in hardness of a food bolus.

Adhesiveness and cohesiveness of each test food bolus changed their characteristics with the progress of mastication. For both the $\mathrm{P}$ and $\mathrm{HB}$ boluses, adhesiveness had a maximum value at the $L$ stage (i. e. immediately prior to swallowing), and cohesiveness increased significantly from the halfway stage of mastication (M stage) to immediately prior to swallowing (L stage) (see Figs. 3 and 4). Peak adhesiveness and increased cohesiveness at the $\mathrm{L}$ stage suggest that a clump bolus may be formed immediately prior to the swallowing of masticated peanuts and hard biscuits, a hypothesis supported by the notion that high adhesive- 
ness is thought to contribute to the formation of a cohesive bolus ${ }^{9}$. In addition, these findings are not inconsistent with Printz and Lucas's new model ${ }^{2}$, where swallowing is thought to commence when food particles bind together as a coherent bolus. Adhesiveness of both the $\mathrm{P}$ and $\mathrm{HB}$ boluses significantly decreased from the $\mathrm{L}$ stage to the $+20 \%$ stage (see Figs. 3 and 4 ). This reduction may be due to continuous salivation from immediately prior to swallowing to the $+20 \%$ stage. During this period, particles in a clump bolus may gradually separate due to excess salivation, and the bolus may fall apart.

In the $\mathrm{RC}$ bolus however, adhesiveness decreased significantly from the $\mathrm{M}$ stage to the $\mathrm{L}$ stage and cohesiveness remained unchanged (Fig. 2). The tongue makes churning movements designed to mix and coat the triturated food with saliva at the L stage of mastication $^{10}$, and the highly adhesive RC bolus required rapid and forceful movement of the tongue at this stage ${ }^{3,5}$. Such tongue movements at the $\mathrm{L}$ stage of $\mathrm{RC}$ mastication may rapidly mix the $\mathrm{RC}$ bolus with saliva, causing a rapid reduction in adhesiveness of the bolus. We have reported that a reduction in the adhesiveness of rice starch paste ${ }^{11)}$ and cooked rice ${ }^{12)}$ can induce earlier swallowing. Taken together, these findings suggest that swallowing of the $\mathrm{RC}$ bolus may commence when adhesiveness is sufficiently reduced.

In conclusion, our results suggest that the swallowing of hard and brittle ( $\mathrm{P}$ and $\mathrm{HB}$ ) boluses commences once a clump bolus has formed, and that the swallowing of a highly adhesive $\mathrm{RC}$ bolus commences once the degree of adhesiveness of the bolus reaches the swallowing threshold. The initiation of swallowing once a clump bolus is formed for hard and brittle food boluses serves to prevent the mis-deglutition of the bolus that passes through the pharynx where the food-way crosses the airway. In addition, triggering the swallowing of a highly adhesive bolus once a sufficient degree of adhesiveness is reached facilitates the ease and safety with which the bolus can move through the pharynx and esophagus.

\section{Acknowledgements}

This study was supported in part by Program for
Promotion of Basic Research Activities for Innovative Biosciences (PROBRAIN).

\section{References}

1) Hutchings, J. B. and Lillford, P. J. : The perception of food texture-The philosophy of the breakdown path. J. Texture Stud. 19: 103-115, 1988.

2) Prinz, J. F. and Lucas, P. W. : An optimization model for mastication and swallowing. Proc. R. Soc. Lond. B 264 : 1715-1721, 1997.

3) Shiozawa, K., Kohyama, K. and Yanagisawa, K. : Influence of ingested food texture on jaw muscle and tongue activity during mastication in humans. Jpn. J. Oral Biol. 41 : 27-34, 1999.

4) Shiozawa, K., Kohyama, K. and Yanagisawa, K. : Food bolus texture and tongue activity just before swallowing in human mastication. Jpn. J. Oral Biol. 41: 297-302, 1999.

5) Bourne, M. C. : Texture profile analysis. Food Technol. 32: 62-66, 1978.

6) Pons, M. and Fizman, S. M. : Instrumental texture profile analysis with particular reference to gelled system. J. Texture Stud. 27 : 597-624, 1996.

7) Manly, R. S. and Braley, L. C. : Mastication performance and efficiency. J. Dent. Res. $29: 448-462$, 1950.

8) Lucas, P. W. and Luke, D. K. : Methods for analyzing the breakdown of food in human mastication. Arch. Oral Biol. 28 : 813-819, 1983.

9) Shiozawa, K., Kohyama, K. and Yanagisawa, K. : Relationship between physical properties of a food bolus and the swallowing threshold during mastication of gel type food. Jpn. J. Oral Biol. $44: 114-119$, 2002.

10) Abd-EL-Malek, S. : The part played by tongue in mastication and deglutition. J. Anat. $89: 250-255$, 1955.

11) Shiozawa, K., Kohyama, K. and Yanagisawa, K. : Influence of adhesiveness of ingested food on human masticatory behavior. Jpn. J. Oral Biol. 39 : 25-33, 1997.

12) Shiozawa, K., Kohyama, K. and Yanagisawa, K. : Cooked rice mastication in humans. Influence of physical property of cooked rice on the human masticatory behavior. J. Masticat. \& Health Soc. 5: 37-42, 1995. 